\title{
WORDS ON THE NET: FAMILY, EDUCATION AND SOCIETY
}

\author{
Alessia Bartolini ${ }^{1}$, Silvia Fornari ${ }^{2}$, Agnese Rosati ${ }^{3 *}$ \\ ${ }^{1}$ Ph.D. Asst. Prof., University of Perugia. Italy. Department of Philosophy, Human and Social \\ Sciences and Education. alessia.bartolini@unipg.it \\ ${ }^{2}$ Ph.D. Asst. Prof., University of Perugia. Italy. Department of Philosophy, Human and Social \\ Sciences and Education. silvia.fornari@unipg.it \\ ${ }^{3}$ Ph.D. Asst. Prof., University of Perugia. Italy. Department of Philosophy, Human and Social \\ Sciences and Education, agnese.rosati@unipg.it \\ * Corresponding Author
}

\begin{abstract}
In this paper we present the findings of an interdisciplinary study on the issues of education, family and society with the aim of enhancing and making possible a multidisciplinary vision which can reflect the unitary quality of knowledge. The various systems, the emerging issues and the current problems -also dealt with in academic research- refer to the metaphor of the net, which expresses an interweaving of reality and aspects which integrate and complicate one another reciprocally. Historical transformations thus have repercussions on society, its models and its customs, involving public and private institutions, such as the time and place of education. For this reason we speak of an education which preserves its official status and formality, but is neither unique nor exclusive, considering that education is also imparted in informal contexts using nonformal pathways and structures. Prospects change and new methods of interpretation are perceived which require multiple and different approaches, including also the epistemological and methodological aspects of the issue. Not a single method to tackle and solve problems, but rather a methodological wealth enabling us to understand the pluralistic nature of society reflected in the transformation of the family, in order to legitimize an educational presence that can go a long way in meeting the natural and cultural needs of each individual.
\end{abstract}

Keywords: interdisciplinary perspective, education, unity of knowledge

\section{INTRODUCTION}

Education, family and society constitute the crucial points in a discussion that has involved educators in different disciplines (pedagogy and sociology) engaged in teaching and research in the Department of Philosophy, Social, Human and Education Sciences at the University of Perugia (Italy). This paper presents a multidisciplinary reading intended to reflect the unitary quality of knowledge, to provide students with the cognitive and linguistic tools for in-depth learning which can increase their knowledge and, above all, their capacity to think consciously about what they have learned. This is of course the meaning of education, aimed at furthering in each individual a transformation of the self, an expression of a consistent correlation between thought and action (Rosati, 2010). Learning, on order to be "transformative", as taught by Asubel 
(2004) and Mezirow (2003), requires a consideration that displays argumentative and metacognitive abilities; to develop those, a new mind-set must be adopted which is not the result of indoctrination, but rather the outcome of an education in thinking. The philosopher Immanuel Kant already emphasized the importance of not conveying thoughts as preconceived by adults and teachers, because their function should be to encourage and support the development of a personal - and therefore original - thinking in their pupils. Critical, creative and complex thinking, as in the analysis of Morin (2001), is also "caring" thinking, as Lipman (2005) suggests; therefore it is new, unusual, and above all the guardian of a tension of values. However, it should be stated that one cannot get an idea of a thing or a phenomenon without possessing the necessary information and knowledge: this is the starting point of the learning process, which will assume its full meaning when individuals will be able to recognize the usefulness of the knowledge they possess: not merely a sum of pieces of information, but "instruments" of knowledge in the exploration of the world. It is in reality that we can perceive a network of experiences, emotions, personal stories, narrations, considerations and thoughts which can be defined as being "in motion", because prospects, views and ways of approaching problems change constantly. Brain plasticity of thought (Ramachandran, 2010) and plasticity of language (Goldberg, 2010; Oliverio 2001) become goals in an education that "takes care" of the person, because it focuses on individual development and works toward its improvement, seeking to promote a recognition of values which is not imposed, but respects freedom (Rosati, 2010, 2011). For this reason the material we offer students becomes "concrete" material for reflection, to increase their awareness of "living in" the world (Natoli, 2008), entering into the network of problems that require not only intellectual fluidity -another educational goal- but also metacognitive skills which can grasp the core of the issues.

\section{THE STUDY}

\subsection{Educational Aims And Expectations in a Changing Society}

Changes in the cultural scenario, which have made our reality increasingly complex (Morin, 2000, 2001, 2008) and fluid (Bauman, 2005) to the point of representing the "old age of the world" (Delsol, 2008), have squeezed thought and language in a concrete dialectic which has taken on a nomadic quality bearing testimony to the wandering (migrant thought), in search of truth and certainty, in a comparison between knowledge and scientific methods. The development of the free, open, pluralistic and "welcoming" thinking is the purpose of this work, arising from the consideration of the problems faced which become the material for analysis and synthesis, with the construction of conceptual maps aimed at framing the issues in every aspect and possible relationship with other themes. The educational process, in fact, takes into account the social, historical, cultural, political and economic factors that characterize the time (Spadafora, 2014), of which we must be aware in order to understand the reasons which - in this context - become material open to reflection. Reflexivity, therefore, becomes the aim which the educational action addresses; an awareness of one's own limits is anchored to the concrete transformative possibilities that education offers. In short, it is a matter of giving an individual the ability to build existential design.

\subsection{Educational Objectives And Life Competence}

Educational objectives will be aimed at the intellectual growth of students, demonstrated by the ability to make an analysis and a synthesis of complex phenomena through the connection between thought, action, and research. The union of those three factors is expressed in linguistic communication and in practical actions. Attributing meaning to events and actions is necessary for guiding individual and collective decisions. This means promoting encounter and comparison with others, in order to identify a common platform of values (Spadafora, 2014, p. 570) in which different persons recognize and join each other; this in turn promotes recognition of one's individual uniqueness and cultural diversity, and opens a path of selfawareness that fosters a consciousness of universality which can accept every peculiarity without coercion.

Personal mature identity, in fact, is achieved through encounters with those other than oneself, which allows one to recognize in others the commonalities which may be shared. This aspect cannot be overlooked in a multicultural historical and cultural context; religions, histories, experiential knowledge and science, despite their apparently divergent appeal, can find common elements to promote greater social cohesion. To sum up, the following can be considered educational objectives: 1) knowledge and self-awareness, i.e. the ability to give the right value to one's emotional experience and to the knowledge acquired; 2) knowledge of the life context and ability to make choices, respecting oneself, others and the environment; 3 ) identification of common social, historical, economic and cultural issues; 4) logical and linguistic mastery, in order to express thoughts coherently and consistently; 5) recognition of the culture of subjectivity, from which individual and collective needs and expectations derive; 6) analysis and comprehension of the changes taking place which contribute to an increased uncertainty and complexity. These objectives, which make up a broader and more articulated educational aim which could be termed "life competence", nourished by critical thinking and enriched by culture, are currently the subject of analysis and research in Relational Pedagogy (Orazi, Pattoia 
and Rosati, 2014), which takes into account a complex set of social phenomena and attempts to outline educational paths which can offer people of "late modernity" (Delsol, 2008) answers to the core questions of existence. It is these very problematic situations which form the content on which to apply autonomous thinking, in order to explain and understand the contexts of life according to a problematic method by which a hermeneutic act of clarification involving what to interpret (object), the interpreter (subject), and the very procedures of interpretation (methodology) can be performed. Complexity therefore becomes category, phenomenon and method, for the processuality and the relationship that are the subject of pedagogical knowledge (science) committed to a search for the meaning of life and reality (Bellatalla, 2005) which require a strong commitment from the educational point of view in order to be consciously understood. Savater (2014) adds: the commitment gives a concrete aspect to the transformative process begun by education, to find motivation and appeal including the emotions (Bocciolesi, 2014) that underlie learning, since they influence individual choice and emerge from the pages of one's own biography.

\subsection{Contents}

The subject matter is aimed at analyzing the processes of diversity and differentiation. In fact: "Ogni soggettività delle diverse persone esprime un progetto di vita che nella scuola, soprattutto, ma anche nella famiglia e nella società dovrà essere attentamente analizzato e valutato per essere compreso. La dimensione della soggettività della persona deve essere sviluppata nella sua complessità" ${ }^{1}$ (Spadafora, 2014, pp. 569-570), and that means staking note of the rapid changes in reality involving individuals and institutions. Family and society are the two macro systems within which each person can grow by developing a personal and social identity; education represents the best means of completing the existential project of each individual. This research, therefore, focuses on those three subjects: education, family and society.

\subsubsection{Education}

Education is necessary for a person to grow and develop freely one's abilities and potential. Education enables us to "read" reality and "inhabit" the world, with awareness and consciousness. We need to believe in education in order not to lose our orientation and be overwhelmed by the problems that everyday life presents. This means that relying on education we can still glean something positive, despite the negative nihilistic and relativistic predictions. We need hope, courage and confidence: these are the educational virtues, Rossi (2014) adds, which educate the younger generations and operate in educational contexts. After all, perspectives and utopian tensions naturally belong to education that is, as Freire says, not only aimed at changing the world, but in particular the people who operate in it. Education, in fact, allows us to imagine better scenarios in the future, provides the tools (knowledge and skills) to conceive projects and lends us that instance of reflexivity that is put into practice when we make a choice among the projects themselves (Wilson, 2014). Practicality, acting and concrete action acquire a different depth with education, since it indicates a reflection which occurs in the practice and validation of experience (Fabbri, 2007, 2012). This is the "transformative" nature that connotes the person who has learned and that shows the transformation when it is put into action. Pondering actions - and therefore the consequences and effects they produce - is a sign of education and evidence of a learning that results in life competence. The individual, to "become a man-person", needs education because education develops one's self-knowledge, within individual limits and possibilities. At a time in history when the imperative is to challenge every limit, as Latouche (2012) charges, thus forcing the possible, the conditions that somehow seem to delineate and contain actions and intentions cannot be ignored. These limits, nevertheless, are not intended as an obstacle to the possible opportunities that education and culture offer to a person in terms of freedom of thought and consciousness; on the contrary, they represent a starting point. To design the "possible" we need a sensible utopia, a propulsion of prospects that only education can give, in order to search for the legitimate meaning of life that derives precisely from the balance of forces with the strategies of thought (Mollo, Porcarelli, and Simeone, 2014), and therefore, of limits with possibilities. Thus one's existence can be planned freely, in the awareness and knowledge of one's inner world similar to that of the "other" which become - in this search for balance - places, spaces and experience.

\subsubsection{Family}

The evolution of the role and social conditions of the family in relation to social, cultural, political and economic factors that are affecting our time have produced a metamorphosis of its constitutive elements which drives us more and more not to talk about the family but about families, plural. Alongside the traditional family there are new families: single-parent, reconstituted, one-person, common-law and same-sex-parent families. This morphological diversity has led to new forms of organization of domestic life, and in particular

1 Translated quotation that appeared in the paper: "Every subjectivity of different people expresses a life project that especially within the school, but also within the family and the society, must be thoroughly analyzed and evaluated to be understood. The dimension of the subjectivity of the person has to be developed in its complexity". 
has redefined roles both within the couple and in the meaning of the concept of parenting. The social roles of men and women have changed and as a consequence the family roles of mothers and fathers have been redefined (Fornari, 2009). Taking into consideration the ongoing social changes, disciplines such as pedagogy, sociology and psychology are called upon to reflect on the relational dimension of humans faced with the hedonistic, individualistic and competitive values that imprison us in a state of "privateness". Human beings are "family beings" and the family - or, rather, families - as a community of people must be reborn not only as a place of affective relationships but also as a place of responsibility, where the fundamental experience of love, altruism and selflessness can take place. Many people nowadays, however, argue that parenting relationships are experiencing a crisis (Bartolini, 2012). More and more frequently parents conduct educational relationships which are ambivalent, oscillating between extremely permissive behavioral models and authoritarian attitudes, with no authoritative point of reference to ease the process of guiding their children into maturity. The adults often seem to fail to recognize their educational duty and the responsibilities inherent in their role; as a result, the importance that parents should represent, and should be recognized by their children as models of life and virtuous behavior, is lacking. Our social context certainly does not facilitate the educational function of families. The families of the new Millennium, in fact, are part of a process of historical change in a global society, and they often come up disoriented. A strongly individualistic and hedonistic society inevitably shapes and influences the relationships that develop within and outside the family; education itself, as an intentional relationship, is not excluded. The atmosphere that young people live and experience in their families provides them with the key to reading and interpreting what is happening around them. As Brezinka (1980, pp.46-47) says: "In una grande società pluralistica si può acquisire l'abilità nella vita solamente se i bambini hanno la possibilità di crescere in comunità legate da sentimenti, ideologicamente unitarie e moralmente sane ed esigenti" ${ }^{2}$. The family should be the first of these communities, and within it young people should have the chance to experience relationships with significant and responsible adults who know how to fill the role assigned to them authoritatively and are aware of their educational role; therefore they will be able to present themselves to, and be recognized by, their children as significant educational models. Pedagogical reflection and educational practices are called upon to stimulate the intrinsic potential of families, so that the family may be reborn as an educational community. Families, in fact, are not only a private subject of relationships; they also embrace the public, social and political sphere, and therefore should not simply be evaluated as a social problem or question to be monitored, but as a valuable resource for those social contexts as a system of primary relationships and place of primary socialization of children. The essence of the family, therefore, must be found in its possibility to establish it self as a place of "umanizzazione degli umani, di personalizzazione delle persone, di esperienza fondamentale dell'amore, ella fiducia, della gratuità, del dono, del disinteresse, della possibilità di riconoscersi senza negarsi, di fare esperienza della difficile conquista della libertà e dell'autonomia senza cessare di sentirsi parte di un universale concreto"3 (Sensi, 2009, p. 90)- beyond the various ways in which today we may choose to start our family.

\subsubsection{Society}

Modern society, which is the result of the revolutionary economic-capitalistic logic, radically transforms the mechanisms of social life, the methods of sharing experience and the ways in which people "associate". Society is, in fact, relationships; a society is built on the social relationship of people who share ideas, spaces and places in which they create groups, from the smallest (families) to the largest (schools, work teams, governments), and in this way its social system is organized. Societies can be studied by identifying the dynamic of reciprocal relationships. Unity is achieved when a social element can establish a dynamic relationship among its constituent parts: although we may view them as single, they are not necessarily individuals but could also be groups which create dynamic social relationships and thus make up a society which "è un'unità che consta di unità"4 (Simmel, 1998, p.18). Society is, therefore, only the name to describe the interactions among individual parts, a concept that takes on an independent character, with an object of study that is subject to its own laws and which may be associated with an autonomous science, sociology.

The task of living in our society at the present time is even more difficult and contorted, not only because our society is complex and fragmented, but because the sense of belonging and of recognition which is

2 Translated quotation that appeared in the paper: "In a large pluralistic society, individuals will acquire the necessary skills in life only if children have the opportunity to grow in ideologically unified and morally healthy and demanding communities linked by feelings".

3 Translated quotation that appeared in the paper: "humanization of humans, customization of people, [the place of] a fundamental experience of love, trust, altruism, giving, disinterest, [the place where people have] the possibility to recognize themselves without denying their selves and experience the difficult conquests of freedom and autonomy, without ceasing to feel part of a concrete universal".

4 Translated quotation that appeared in the paper: "is a unit consisting of units". 
necessary to achieve social unity is more and more difficult to trace and understand. Thus we find ourselves having to redefine the borders of our society and, in doing so, we cannot avoid questioning our ability to piece together the puzzle of society; we must find definite boundaries of belonging and as a consequence rethink our experiences, to arrive at what Ulrich Beck thinks is necessary: To build one's own life (Beck, 2008). In such a situation our social tasks are certainly subject to constant, fragmented and ambivalent pressures; it becomes necessary to be good creators, builders of our lives, making our own selves in order to meet "the challenges of a complex society." We realize that the very words used to express the mood and the difficulties characterizing this psycho-social path are undoubtedly examples of the social complexity of our time. Perhaps we could say that the real link among individuals who make up the present society is the commonality of the pervasive state of malaise and emotional uncertainty felt by us all. Being uncertain means having no assurances, no certainties for the near future, having no chance to build, plan or think actively; if this is the social adhesive of the present time, perhaps we can be cheered because it means that each of us is not alone in this arduous social adventure so fraught with difficulties. In the commonality of uncertainty we should be able to find some kind of reassurance. The complex and constant state of transformation eternally in process determines the constant shifting of the boundaries of reference in society, and consequently the changing of the rules of the social game (reciprocal exchanges of communication).

\subsection{Educational Strategies: Mind Maps and Concept Maps}

The use of the concept maps methodology represents a form of communication aimed at supporting and enhancing learning. Visual representations of concepts are an effective educational strategy for achieving learning goals, as they stimulate complex cognitive processes such as: symbolization, the relationship between concepts, interpretation, assumptions, deductions and checks. An initial consideration concerns the distinction between the use of mind maps and concept maps. Mind maps consist of a technique of graphic representation, theorized by Buzan (2012). It is an instrument committed to creativity, to the storage and annotation of knowledge in a personal way. We proceed by inserting and recombining elements in the map dynamically, using only two types of connections: a hierarchical structure (also called branches) connecting each element to the one preceding it, and an associative structure (also called associations) connecting hierarchically arranged elements in different parts of the map. Concept maps, on the other hand, are an effective instrument for knowledge representation, as claimed by Novak (2012); from a central idea we can reorganize the knowledge articulating our thought through both hierarchical and transverse links since the map is organized in a networking model. In the hands of a wise teacher, concept maps can be a useful strategy for fostering significant learning in students. Concept maps, allowing one to identify the relationships between concepts, help students to organize independently what they are learning. Concept maps may also be very useful for organizing our thoughts or for planning a task, for those are processes that require a reworking of our own thought. In conceptual maps the points are connected by relationships, which become visible through lines and descriptive tags that are used to clarify the type of relationship.

\subsection{Justification for the Selection}

The choice of conceptual maps seems appropriate when a substantial amount of information is involved, i.e. when the amount of material to be learned is large. Furthermore, conceptual maps meet the following requirements: a) activation of cognitive processes; b) translation of foreknowledge, sometimes disorganized, in well-organized systems; c) construction of a cognitive "scaffold" (scaffolding process).

\section{CONCLUSIONS}

Interdisciplinary collaboration, exchange of prospects and integration of knowledge become indispensable in research involving the education of the human person. In the "great mosaic of education" (Mattei, 1998, p.83) knowledge, masteries and skills in fact converge to contribute to the determination of personal identity, which is formed and becomes self-awareness in the contexts of life. Starting with the family, one arrives at the society based on one's role, political beliefs, religious sentiments, experiences and vicissitudes to which an individual's expectations, needs desires and emotions are bound. These considerations may be sufficient for understanding how complex is the education of the person and how a pluralistic approach - which only a dialogue among the sciences can offer - is necessary in order to develop a greater understanding.

\section{REFERENCE LIST}

Ausubel, D. P. (2004). Educazione e processi cognitivi. Guida psicologica per gli insegnanti. Milano, Franco Angeli.

Bartolini, A. (2012). La famiglia. Una cultura delle relazioni. Perugia, Morlacchi.

Bauman, Z. (2005). Liquid Modernity. Polity Press, London. 
Beck, U. (1992),(2008). Risk Society. SAGE Publications.

Bellatalla, L. (2005). Pedagogia e Filosofia della scienza: questioni generali. Ricerche Pedagogiche. Rivista. Anno XL. n.155, Aprile -Luglio 2005. Parma:9-16.

Bocciolesi, E. (2014). E-Motion in the New Books: When the e-Book Captures the Reader Emphatically. «International Journal of the Book», 12 (1):7-11.

Brezinka, W. (1980). Metateoria dell'educazione. Introduzione ai fondamenti della Scienza dell'educazione, della Filosofia dell'educazione e della Pedagogia pratica. Roma, Armando.

Buzan, B. e T. (2012). Mappe mentali. Come utilizzare il più potente strumento di accesso alle straordinarie capacità del cervello per pensare, creare, studiare. Urgnano. Alessio Roberti Editore.

Delsol, C. (2008). Elogio della singolarità. Macerata. Liberilibri.

Fabbri, L. (2007). Comunità di pratiche e apprendimento. Per una formazione situata. Roma, Carocci.

Fabbri, L. (2012). Le pratiche professionali. Progettazione e apprendimento nei contesti lavorativi. Roma, Carocci.

Fornari, S. (ed.) (2009). Essere o fare famiglia. La famiglia come istituzione sociale plurale. Torino, UTET.

Giddens, A. (1991). The Consequences of Modernity. Stanford University Press.

Goldberg, E. (2010). La sinfonia del cervello. Milano, Ponte alle Grazie.

Latouche, S. (2012). Limite. Torino, Bollati-Boringhieri.

Lipman, M. (2005). Educare al pensiero. Milano, Vita e Pensiero.

Mattei, F. (1998). Sapere pedagogico e legittimazione educativa. Roma, Anicia.

Mezirow, J. (2003). Apprendimento e trasformazione. Il significato dell'esperienza e il valore della riflessione nell'apprendimento degli adulti. Milano, Raffaello Cortina.

Mollo, G., Porcarelli A., Simeone D. (2014). Pedagogia sociale. Brescia, La Scuola.

Morin, E. (2000). La testa ben fatta. Riforma dell'insegnamento e riforma del pensiero. Milano, Raffaello Cortina.

Morin, E. (2001). I sette saperi necessari all'educazione del futuro. Milano, Raffaello Cortina.

Morin, E. (2008). II metodo 4. Le idee: habitat, vita, organizzazione, usi e costumi. Milano, Raffaello Cortina.

Natoli, S. (2008). Stare al mondo. Escursioni nel tempo presente. Milano, Feltrinelli.

Novak, J. (2012). Costruire mappe concettuali. Strategie e metodi per utilizzarle nella didattica. Trento, Centro Studi Erickson.

Oliverio, A. (2001). La mente. Istruzioni per l'uso. Milano, Bur.

Orazi, R., Pattoia, M., Rosati, A. (2014). Pedagogia relazionale e sicurezza sociale. Percorsi di cittadinanza consapevole. Napoli, Liguori.

Ramachandran, V. S. (2010). Che cosa sappiamo della mente. Gli ultimi progressi delle neuroscienze raccontati dal massimo esperto mondiale. Milano, Mondadori.

Rosati, A. (2011). Nuove frontiere della pedagogia. Educazione e neuroscienze. Roma, Anicia.

Rosati, A. (2010). Per una Filosofia dell'educazione. Roma, Anicia.

Rossi, B. (2005). Intelligenze per educare. Sull'identità professionale dell'insegnante. Milano, Guerini Scientifica.

Rossi, B. (2014). Il lavoro educativo. Dieci virtù professionali. Milano, Vita e Pensiero.

Rossi, B. (2015). Pedagogia dell'arte di vivere. Intelligenze per una vita felice, Brescia, La Scuola.

Savater, F. (2014). Piccola bussola etica per il mondo che viene. Roma-Bari, Laterza.

Sennett, R. (2004). Rispetto. La dignità umana in un mondo di diseguali. Bologna, il Mulino. 
Sensi P. (2009). Della famiglia. Abbozzo di meditazione sull'eidos dell'istituzione familiare, in S. Fornari (ed), Essere o fare famiglia. La famiglia come istituzione sociale plurale. Torino, UTET.

Simmel, G. (1998). Come è possibile la società? Torino. Comunità editrice.

Spadafora, G. (2014). La pedagogia dei prossimi anni. Riflessioni e suggestioni, in Minichiello G. et Al. (ed), La persona come discontinuità ontologica e l'educazione come ultima narrazione. Saggi in onore di Giuseppe Acone. Lecce, Pensa: 561-574.

Wilson, E.O. (2014). II significato dell'esistenza umana. Milano, Codice edizioni.

\section{Author contributions}

This work has been jointly designed by the authors. Alessia Bartolini wrote the paragraphs: Abstract; 1.3.2. Family; 1.4. Educational Strategies: Mind Maps and Concept Maps; 1.5. Justification for the Selection; References. Silvia Fornari wrote the paragraphs: Abstract; 1.3.3. Society; References; Final Review. Agnese Rosati wrote the paragraphs: Abstract; Introduction; 1.1.Educational Purposes and Expectations in a Changing Society; 1.2. Educational Objectives and Life Competence; 1.3. Contents; 1.3.1. Education; 3. Conclusions; References. 